\title{
ОСОБЛИВОСТІ РОЗВИТКУ ОСВІТНЬО- ПЕДАГОГІЧНОГО ПРОГНОЗУВАННЯ В УКРАЇНІ В ІМПЕРСЬКУ ДОБУ (1900 - 1917 рр.)
}

\author{
Черняк Серхій Геннадійович, \\ PhD, доцент, учений секретар, Київська муніџипальна академія естрадного та ииркового \\ мистеитв, м. Київ, Украӥна
}

DOI: https://doi.org/10.31435/rsglobal_wos/31052020/7096

\begin{tabular}{l} 
ARTICLE INFO \\
Received: 24 March 2020 \\
Accepted: 21 May 2020 \\
Published: 31 May 2020 \\
\hline
\end{tabular}

\section{KEYWORDS}

educational and pedagogical

forecasting,

education system,

reforms,

imperial era.

\begin{abstract}
The article is devoted to the development of educational and pedagogical forecasting in Ukraine in the imperial era $(1900$ - 1917). The author emphasizes that at the turn of the XIX - XX centuries there are a number of new concepts of education and upbringing, which together formed a qualitatively new theoretical basis for the development of schooling. The teacher notes that the beginning of the twentieth century is marked by a manifestation of the national crisis, which was exacerbated by the defeat of Russia in the war with Japan, as well as the events of the first democratic revolution of 1905 - 1907 in the Russian Empire. The scientist emphasizes that the development of educational and pedagogical forecasting in the early twentieth century, in particular in the field of general secondary education, due to the initiative of the Ministry of Education on April 29, 1900 program of secondary school reform. The author provides information on teacher training during the specified period. The researcher notes that the government of Nicholas II, constantly changing the ministers of education (M.P. Bogolepov, P.S. Vannovsky, etc.), practically did not allow even the adoption of documents aimed at reforming education in the new socio-economic conditions, not to mention already about their implementation, although many of the proposed projects, including the Ministers of Education, contained many progressive ideas and provisions. The author reveals the potential of the Ministry of Education in the field of vocational education.
\end{abstract}

Citation: Cherniak S. G. (2020) Features of the Development of Educational and Pedagogical Forecasting in Ukraine in the Imperial Era (1900 - 1917). International Academy Journal Web of Scholar. 5(47). doi: 10.31435/rsglobal_wos/31052020/7096

Copyright: (C) 2020 Cherniak S. G. This is an open-access article distributed under the terms of the Creative Commons Attribution License (CC BY). The use, distribution or reproduction in other forums is permitted, provided the original author(s) or licensor are credited and that the original publication in this journal is cited, in accordance with accepted academic practice. No use, distribution or reproduction is permitted which does not comply with these terms.

Постановка проблеми, її зв'язок з важливими проблемами. На сьогодні актуальною постає проблема впорядкування прийомів та операцій теоретичного та практичного освоєння дійсності, що спрямовується на розроблення прогнозу, який являє собою спосіб пошуку педагогічного майбутнього. Намагання свідомо й глибоко вивчати окремі питання прогнозування системи освіти в цілому та педагогічної школи зокрема дозволяють знайти і сформулювати якісні ознаки i структурні елементи педагогічних явищ i процесів, які безпосередньо чи опосередковано зачіпають інтереси споживача освітніх послуг, представників наукової спільноти. У зв'язку з цим особливого значення набуває висвітлення історичного досвіду розвитку освітньо-педагогічного прогнозування в Україні на початку XX століття, який уважаємо джерелом оновлення сучасної вищої школи.

Аналіз останніх досліджень і публікацій. Вивченню проблеми прогнозування присвятили свої розробки окремі науковці. Так, розкрито теоретичні і методологічні засади прогнозування розвитку загальної середньої освіти, його змістову і процесуальну складові (Л.А. Онищук), розроблено модель прогнозування розвитку загальноосвітнього навчального 
закладу в системі внутрішньо шкільної методичної роботи (Д.О. Пузіков), обгрунтовано методи педагогічного прогнозування та їх застосування (А.П. Панфілова), вивчено теоретикометодичної основи прогнозування розвитку педагогічних наук i педагогічної практики, визначено iї предмет та структуру, обгрунтовано мету, завдання дидактичного прогнозування як важливої складової педагогічного прогнозування (О.М. Топузов). Однак, історичний досвід, наукові концепції розвитку освітньо-педагогічного прогнозування в Україні на початку XX століття залишаються недостатньо дослідженими.

Мета статті полягає у здійсненні цілісного наукового аналізу особливостей розвитку освітньо-педагогічного прогнозування в Україні періоду 1900 - 1917 pp.

Виклад основного матеріалу. На рубежі XIX - XX століть 3'являється цілий ряд нових концепцій освіти і виховання, що склали у своїй сукупності якісно нову теоретичну базу розвитку шкільництва. Провідними чинниками розвитку педагогічної думки у цей період стали такі: невідповідність школи вимогам часу, перш за все, потребам промислового виробництва у кваліфікованих робітниках і науково-технічних кадрах, що стала не тільки освітньою, а й державною проблемою; розвиток науково-технічного прогресу, який вимагав надання учням у школі значно більшого обсягу знань, умінь та навичок; накопичення педагогікою та психологією достатньої для побудови нових концепцій кількості знань про природу дитинства та пізнавальні процеси [13, с. 110].

Освітня політика Миколи II, який вступив на російський престол у 1894 році, була прямим продовженням політики Олександра III. Значний вплив мали монархічні елементи, які групувалися навколо провідного ідеолога урядової реакції 80-х pp. - обер-прокурора святішого Синоду К.П. Побєдоносцева. В середині 90-х рр. він розробив систему поглядів на школу і освіту, якою, на його думку, повинна була керуватися урядова бюрократія. Протиставляючи розумове виховання учнів ремісничій підготовці, необхідній для життя, К.П. Побєдоносцев визначав, що погана та школа, яка відриває людину від іï середовища, позбавляє сім'ю робочої сили, розбещує дітей. Ідеалом народної школи проголошував таку, в якій учні оволодівають мінімумом знань, навчаються любити і боятись Бога, любити батьківщину і поважати батьків. За його переконанням, поліпшення суспільної моралі можна досягти не турботою про розумове виховання, а щоденними вправами. Для цього пропонувалося тримати людей у суворому підпорядкуванні нормам громадянського життя, щоб його порушення каралось, а виконання заохочувалось [11, с. $400-401]$.

Відзначимо, що початок XX століття позначений проявом загальнонаціональної кризи, яка загострилася у зв'язку з поразкою Росії у війні з Японією, а також подіями першої демократичної революції 1905 - 1907 pp. в Російській імперії. Початок революції поклали події 9 (22) січня 1905 р. у Петербурзі. У цей день була розстріляна багатотисячна мирна демонстрація робітників, яка прямувала 3 петицією до царя. У ній містилося прохання покращити умови їхнього життя. Демонстрацію очолював священник Георгій Гапон. Було вбито понад 200 чоловік і кілька сотень поранено. Кривава неділя у столиці викликала хвалю обурення у всій імперії. Країною пронеслася хвиля страйків, які охопили й українські міста, зокрема Катеринослав, Харків, Київ, Миколаїв, Одесу. Страйкарі висунули не лише економічні, але й політичні гасла (особливо у першій половині жовтня 1905 р.). Селянські заворушення 1905 р. охопили більше половини всіх повітів України. Широкого розмаху набув i студентський рух - студенти вимагали автономії університетів, брали участь у робітничих мітингах і демонстраціях. Активізували свою діяльність опозиційні політичні сили - від об'єднань земських діячів до соціал-демократів і соціалістів-революціонерів [31, с. 256]. Проте, маємо відзначити, що 3 метою збереження державного ладу та громадського спокою порушників ув'язнювали на термін понад 6 місяців, обмежували в праві вибору місця проживання понад 1 рік та підлягали нагляду поліції протягом року [19].

Розвиток освітньо-педагогічного прогнозування на початку XX століття, зокрема в галузі загальної середньої освіти, зумовлений ініціативою Міністерства народної освіти від 29 квітня 1900 року програмою реформування середньої школи, основні положення якої такі: поліпшення матеріального становища й фахової підготовки вчителя; збереження існуючих типів навчальних закладів - гімназій і реальних училищ за умови надання їм більш національного характеру; приділення більшої уваги питанням морального і фізичного виховання учнів; унесення змін до навчальних планів гімназій і реальних училищ, ввести вивчення латинської мови 33 класу, грецької - 34 або навіть 3 5; грецька мова обов'язкова для тих, хто вступатиме на історикофілологічні факультети; збільшення кількості годин у реальних училищах на вивчення 
загальноосвітніх предметів, зокрема нових мов, відкриття 8 класу; дозвіл випускникам реальних училищ вступати на фізико-математичний та медичний факультети університетів; розробка єдиних навчальних програм для початкових класів 3 метою полегшення переходу з реальних училищ у класичні гімназії і навпаки відкриття в маленьких містах загальних прогімназій, об'єднаних середніх шкіл з біфуркацією 35 класу 3 двома відділеннями (гімназійне і реальне); послаблення надмірної регламентації навчального процесу з метою посилення творчості серед учительства, а також надання товариствам і приватним особам широкої можливості відкривати середні школи нових типів. Таким чином, Міністерство народної освіти спрямовувало свою діяльність на поступове зближення гімназійної (формальної) та реальної (матеріальної) освіти через створення єдиних навчальних планів для початкових класів, розробки нових типів навчальних закладів з метою створення єдиної школи [1, с. 29].

У віднайдених нами архівних джерелах міститься інформація щодо відповідності початкових училищ Міністерства народної освіти державним і церковним інтересам у Південно-Західному регіоні, доцільності впровадження ідей релігійно-морального виховання [9]. Педагогічний аспект заявленого питання врегульовано Статутом Київської спілки поширення освіченості та просвіти [34]. Також маємо засвідчити факт уведення цензури. Листом Харківського губернатора від 16 січня 1902 р. не допускалися до друку статті, в яких досліджувалися тимчасові правила студентських організацій, затверджених Міністерством народної освіти 22 грудня 1901 p. [26]. Іншим листом попечителя Харківського навчального округу від 08 березня 1901 р. регламентовано вимоги щодо педагогічної діяльності, а саме необхідність безпосереднього спілкування з дітьми. Наголошено, що будь-яке викладання має відбуватися відповідно до рівня усвідомлення освіченості та розвитку учня, а також 3 урахуванням його індивідуальності [25].

Вагомого значення набуває розвиток виховного потенціалу. Зокрема, у столицях $\mathrm{i}$ губернських містах облаштовувались виховні пансіони при середніх навчальних закладах. Загальноосвітня школа мала бути триступенева: нижча із завершеним курсом освіти, середня школа різних типів, також із завершеною освітою та середня школа 3 підготовкою до вступу до університету [28, с. $703-704]$.

Також маємо відомості щодо підготовки вчителя протягом означеного періоду. Так, у Харківському університеті з 1900 р. запроваджуються різноманітні педагогічні курси, зокрема "Загальний огляд педагогічних теорій XVII та XIX ст." і спецкурси по персоналіях, наприклад, про "педагогічні погляди та систему Й.Г. Песталоцці". На засіданні історико-філологічного факультету 08 грудня 1901 р. було визнано бажаним змінити список кафедр, установлений Статутом 1884 р., започаткувавши 16 кафедр замість 11. Пропонувалось у тому числі відновити кафедру педагогіки [6, с. 130].

На початку XX століття виявлено дві основні тенденції. Перша простежується в тому, що вчителів професійно готують на кафедрах педагогіки та на декотрих факультетах університетів, а для інтеграції високого рівня загальнонаукової університетської та поглибленої педагогічної освіти в університетах розробляють детальні програми з педагогіки, теорії виховання, дидактики, історії педагогіки, окремих методик. Друга - у створенні педагогічних інститутів для осіб 3 вищою (університетською) освітою. Поєднання практичної викладацької діяльності і спеціальної підготовки вважалося оптимальним для педагогічної освіти [7, с. 145 - 146].

Маємо зауважити, що уряд Миколи II, постійно змінюючи міністрів освіти (М.П. Боголєпов, П.С. Ванновський та ін.), практично не давав можливості навіть прийняття документів, спрямованих на реформування освіти в нових соціально-економічних умовах, не кажучи вже про їх реалізацію, хоча в багатьох пропонованих проектах, у тому числі й міністрів народної освіти, містилося багато прогресивних ідей і положень [11, с. 402]. 29 квітня 1901 р. через попечителів навчальних округів було запропоновано радам університетів і відповідним колегіям в інших вищих школах висловити власне бачення про бажані зміни в статутній діяльності. Зокрема, визнано доцільним повернутися до засад автономії й узаконити студентські організації. Протягом 1901 - 1902 навчального року було зроблено спроби щодо введення Тимчасових Правил про студентські організації по курсам і факультетам [28, с. 708].

Нами віднайдено наказ Міністерства народної освіти від 28 листопада 1901 року про створення Київської спілки класичної філології та педагогіки. Організацію засновано з метою дослідження наукових питань за усіма галузями класичної філології; розробки й обговорення питань, дотичних до викладання класичної філології та педагогіки [35, с. 636]. 
На початку XX століття потенціал Міністерства народної освіти було зосереджено також у галузі професійної освіти за такою системою [28, с. 729]:

1) для підготовки професійних робітників і майстрів функціонували початкові ремісничі школи та школи ремісничих учнів, в яких навчалися особи, які закінчили курс початкових училищ;

2) для підготовки майстрів - ремісничі училища, до яких зараховували осіб, які закінчили курс двокласних сільських училищ;

3) для підготовки техніків - технічні училища з контингентом учнів, які закінчили курс міських чотирикласних училищ.

Листом Міністерства народної освіти від 22 січня 1904 р. до обіймання окремих посад у навчальних закладах допускалися особи польського громадянства, окрім посад керівників, інспекторів гімназій та реальних училищ, учителів історії та російської мови зі словесністю [20]. Зауважимо, що обговорення і розробка питань, що належать до галузі виховання i навчання, здійснено на рівні Статуту педагогічного відділу історико-філологічної спілки при Імператорському Харківському університеті [36]. Результати діяльності Київської педагогічної спілки було відображено у відповідному звіті [16]. Загальні положення педагогічної діяльності представлено на рівні Статуту Всеросійського Союзу учителів і діячів народної освіти [32].

Маємо відзначити, що згідно з Указом Імператора від 28 серпня 1904 р. особи, які успішно закінчили вищі навчальні заклади, але не мали вчительського звання, можуть бути затверджені на займаній посаді міністром народної освіти на основі характеристик безпосереднього керівника 3 урахуванням знання необхідної дисципліни, педагогічних здібностей, працелюбства, рис характеру тощо [23].

Революційна хвиля 1905 р. змусила уряд до заспокоєння освітніх потреб населення, внаслідок чого Міністерство освіти 20 лютого 1907 р. внесло на розгляд другої Державної Думи (перша Державна Дума була розігнана урядом 7 липня 1906 р., проіснувавши всього 72 дні) законопроект про введення загального навчання, що базувався на таких засадах: 1) всі діти - хлопці і дівчата - у віці від 8 до 11 років повинні пройти курс 4-річної школи; 2) школа має обслуговувати населення в районі радіусом не більше 3 верст; 3) кількість учнів на одного вчителя має бути не більше 50; 4) учитель повинен мати встановлену законом освіту; 5) земства дістають від держави допомогу - 360 крб. на вчителя та 60 крб. на законовчителя щорічно; 6) загальне навчання має бути здійснене протягом 10 років; 7) навчання в школі має бути безплатне; 8) організація та ближче завідування народними школами покладається на органи місцевого самоврядування під доглядом i керуванням Міністерства народної освіти [29, с. 426 - 427].

Станом на 1902 р. в Київській губернії налічувалося 2357 навчальних закладів, 168775 вихованців у них. У м. Києві перебувало 174 заклади [14]. Станом на 1905 р. у Київському навчальному окрузі було 25 гімназій та 2 прогімназії [17]. Також маємо засвідчити факт набуття з 1901 р. поширення студентських рухів у різних навчальних округах Російської імперії [2], а також заборони тілесних покарань учнів нижчих і середніх навчальних закладів Міністерства народної освіти [18].

Нами віднайдено циркуляр по управлінню народними училищами. Зокрема, в офіційній частині документа розміщено розпорядження по Міністерству народної освіти, керівництва Київського навчального округу, директорів та інспекторів народних училищ по Київській губернії. Неофіційний розділ представлений поглядами на завдання народної школи [37]. Також нами опрацьовано Статут Всеросійського союзу учителів і діячів народної освіти. Документ відображає професійні та політичні ознаки спілки [33].

Певний інтерес представляє журнал "Вісник народної освіти", який являє собою щомісячне інформаційне довідкове видання з питань загальноосвітньої і професійної школи перших двох ступенів, дошкільної та позашкільної освіти, освіти дорослих, самоосвіти [10]. Також привертає увагу цикл лекцій народного вчителя, директора народних училищ Т.Г. Лубенця, який наголошував, що нова школа має бути наближена до природи, до сучасних суспільних вимог, важливих з тієї точки зору, що вони змінюють існуючі методи викладання [30]. Також важливим уважаємо лист щодо патріотичного виховання учнів. Зокрема, в документі наголошується, що розумно керована школа має прагнути до виховання учнів в істинно патріотичному дусі, відданості державі, власному народові, повазі до минулого та віри в його майбутнє, збереження заповітів його історії [22].

Новий етап розвитку освітньої справи на Україні пов'язаний із піднесенням на початку XX століття демократичного руху учнів, студентів, учителів. Революційні події 1905 року мали свої наслідки, серед усього іншого, пожвавлення трансформаційних процесів у сфері освіти. 
Так, під гаслом вимоги "загальної та обов'язкової народної освіти за державний рахунок" масово виникають різного роду об'єднання і товариства учителів, освітянських діячів, батьків тощо. Новоутворені спілки діяли на основі програм, статутів, у більшості з яких було прописано вимогу реорганізації сфери народної освіти на засадах свободи, демократії, яка передбачала б безкоштовне обов'язкове навчання, виведення із переліку обов'язкових предметів Закону Божого, а також вирішення мовного питання у контексті дозволу викладання рідною мовою, українською, у всіх типах шкіл [8, с. 103 - 104].

Вже 16 жовтня 1905 р. студентські збори в Київському університеті ухвалили домагатися заснування в університеті чотирьох кафедр (української мови, літератури, історії та права) з українською викладовою мовою та подали про те петицію до професорської ради за підписом понад 1400 студентів. Ректор університету Н. Цитович заявив студентам, що університет є загальнодержавна інституція, а тому не можна допустити в мурах університету читання лекцій іншою мовою, ніж російською. Студенти вирішили боротися доти, доки не досягнуть своєї мети. Їх підтримали не лише студенти і студентки різних університетів і вищих жіночих курсів по інших містах, але й громадянство. Так, наприклад, чернігівські українці і українки звернулися до професорської ради Київського університету з петицією про заснування в Київському університеті кафедр української мови і літератури, історії, етнографії та звичаєвого права. У 1906 р. історико-філологічний факультет Київського університету вдався 3 проханням до міністра освіти завести дві українські кафедри - історії та літератури [29, с. 442].

Починаючи з 1905 р. на території України з'являється мережа "Просвіт" як громадських культурно-освітніх товариств. Необхідно зауважити, що діяльність "Просвіт" була нерозривно пов'язана $з$ українізаційними процесами в середовищі духовенства, частина якого активно відстоювала право українського народу вивчати біблійні тексти та молитви українською мовою. Відновлення діяльності "Просвіт" за доби Центральної Ради (08.03.1917 - 30.04.1918) відбувалося на основі становлення незалежності української держави. Основними принципами, на яких формувалася система освіти України, стали [12, с. 243 - 244]:

- для початкової школи: її світський характер, загальність, обов'язковість та безплатність;

- для семирічної школи: загальнодоступність;

- д для системи освіти національних меншин: рівноправність;

- для приватних навчальних закладів: право на організацію навчання та рівноправне існування $з$ державними школами.

Маємо зауважити, що під впливом революційних подій 1905 р. жінкам було відкрито доступ в університети на правах вільних слухачок. По всій країні відкриваються десятки вищих жіночих навчальних закладів. Найбільшими з них на Україні були Київські, Одеські, Харківські жіночі курси та медичні інститути [5, с. 213]. Важливою подією стало відкриття загальноосвітніх курсів для народних учителів при Київському Фребелівському товаристві [15]. Законом від 04 березня 1906 р. було відкрито загальноосвітні курси для учителів початкових училищ [21]. У цілому ж початок XX століття характеризується уведенням шкільної мережі початкової освіти, зокрема у м. Києві [24].

У 1907 р. власний проект загального навчання в Росії виробило петербурзьке товариство "Ліга освіти", на чолі якої стояв відомий освітній діяч Генрик Фальборг. Згідно 3 цим проектом треба було відкрити 154088 шкіл першого ступеня (4-річні школи для дітей у віці від 8 до 11 років), 17390 шкіл другого ступеня (для одної п'ятої частини дітей у віці від 12 до 15 років) та 2114 шкіл третього ступеня (для одної двадцятої частини дітей від 16 до 18 років). Були ще й інші проекти, але Державна Дума - 3 черги третя - 1911 р. ухвалила проект, що його склала думська комісія народної освіти з деякими змінами проти законопроекту Міністерства освіти 1907 р. Однак Державна Рада відхилила законопроект Державної Думи. Після чого міністр освіти вніс 27 серпня 1916 р. до Державної Думи - з черги четвертої - новий законопроект про запровадження загального навчання, але Дума так i не встигла його розглянути, бо незабаром повстала революція [29, с. 427]. Маємо зауважити, що передреволюційні настрої громадян Російської імперії відображені у відповідних звітах [4].

Нами опрацьовано Положення про вищі початкові училища, що забезпечують завершену початкову освіту. Навчальний план закладу становлять такі дисципліни: Закон Божий, російська мова і словесність, арифметика і початкова алгебра, геометрія, географія, історія Росії, фізика і природознавство, малювання і креслення, співи, фізичні вправи, трудове навчання. Мова викладання - російська. При училищах відкривалися додаткові класи або 
курси: педагогічні, поштово-телеграфні, бухгалтерські, будівельні, електротехнічні, сільськогосподарські, ремісничі. До першого класу зараховували дітей від 10 до 13 років, які завершили однокласне початкове училище Міністерства народної освіти [27]. Оптимізації освітньо-виховного процесу сприяло заснування в Київській губернії Училищних Рад [3].

Висновки. Підсумовуючи вищезазначене, відзначимо, що на ниві здобутків освітньопедагогічного прогнозування початку XX століття в соціокультурному контексті знаходимо принципові розробки системи освіти, виховання, педагогічних концепцій, орієнтованих на розвиток педагогічного мислення та педагогічної культури. Особливості розвитку освітньопедагогічного прогнозування в Україні періоду 1900 - 1917 рр. полягають в наступному:

1. Відповідність системи освіти державним і церковним інтересам країни в цілому, та регіону зокрема. Проблема освітньо-педагогічного прогнозування постає об'єктивним соціальнопедагогічним явищем, провідними чинниками якого стали невідповідність школи вимогам часу, потреба промислового виробництва у кваліфікованих кадрах, науково-технічний прогрес.

2. Розвиток виховного потенціалу через систему пансіонатів при середніх загальноосвітніх закладах, який являе собою процес поетапного опанування дисциплін педагогічного циклу, визначає сформовані вміння та навички, забезпечує оволодіння основами виховної діяльності.

3. Підготовка вчителя в класичних університетах і педагогічних інститутах, що $є$ впорядкованою сукупністю складових, хронологічних періодів, які характеризують зміст підготовки у відповідних соціально-економічних реаліях.

4. Поширення студентського самоврядування через механізми університетської автономії. Специфіка студентського руху визначається освітньою практикою. Зміст і структура студентського самоврядування зумовлена Тимчасовими Правилами про студентські організації $1901-1902$ pp.

5. Концентрація потенціалу в галузі професійної освіти за трирівневою системою підготовки професійних робітників і майстрів через ремісничі школи, ремісничі училища, технічні училища.

6. Доступ в університети жінок на правах слухачок через відкриття загальноосвітніх курсів. Початок XX століття характеризується введенням шкільної мережі початкової освіти, зокрема у м. Києві.

\section{ЛІТЕРАТУРА}

1. Березівська Л. Д. Реформування шкільної освіти в Україні у XX столітті: монографія / Л.Д. Березівська. Київ: Богданова А. М. 2008. 406 с.

2. Дело о распространении студенческих движений в учебных округах, 1901 г. Центральний державний історичний архів України у м. Києві, ф. 707, оп. 262, спр. 3, арк. 1 - 48.

3. Дело об учреждении в Киевской губернии Училищных Советов Министерства народного просвещения, 1907 г. Центральний державний історичний архів України у м. Києві, ф. 442, оп. 660, спр. 64, арк. 1 - 7.

4. Дело с всеподданнейшим отчётом по Подольской губернии за 1906 и 1907 год. Центральний державний історичний архів України у м. Києві, ф. 442, оп. 638, спр. 201, арк. 1 - 16.

5. Дем'яненко Н. М. Загальнопедагогічна підготовка на Київських вищих жіночих курсах (1878 - 1920 рр.) / Н.М. Дем'яненко // Педагогіка і психологія. 1997. № 4. С. 211 - 216.

6. Дем'яненко Н. М. Загальнопедагогічна підготовка вчителя в Україні (XIX - перша третина XX ст.): Монографія. Київ: ІЗМН. 1998. 328 с.

7. Дем'яненко Н. М. Загальнопедагогічна підготовка вчителя у вищих закладах освіти України в XIX - на початку XX ст. / Н.М. Дем'яненко // Педагогіка і психологія. 1998. № 4. С. 141 - 150.

8. Джаман Т. В. Історія педагогіки України: навч. посіб. / Т.В. Джаман. Львів: Новий світ - 2000. 2018. 288 с.

9. Доклад Киевского епархиального училищного совета о состоянии народного образования в Киевской епархии. Центральний державний історичний архів України у м. Києві, ф. 127, оп. 997, спр. 163, арк. $1-12$ зв.

10. Журнал "Вестник народного образования", 01 августа 1911 г. Центральний державний історичний архів України у м. Києві, ф. 707, оп. 229, спр. 150, ч. 1, арк. 13 - 17.

11. Зайченко I. В. Історія педагогіки. У двох книгах. Книга II. Школа, освіта і педагогічна думка в Україні / І.В. Зайченко. Київ: Видавничий дім "Слово". 2010. 1032 с.

12. І Історія педагогіки / за ред. М.В. Левківського, О.А. Дубасенюк. Житомир: ЖДПУ. 1999. 336 с.

13. Левківський М. В. Історія педагогіки [текст]. Науково-популярне видання / М.В. Левківський, Д.І. Пащенко. Київ: Видавництво "Центр учбової літератури", 2017. 380 с.

14. Обзор Киевской губернии за 1902 год. Центральний державний історичний архів України у м. Києві, ф. 442, оп. 633, спр. 496, арк. 157 - 158. 
15. Относительно открытия курсов при Киевском Фребелевском обществе, 1911 г. Центральний державний історичний архів України у м. Києві, ф. 442, оп. 664, спр. 12, арк. 89.

16. Отчёт Киевского педагогического общества взаимной помощи за 1904 г. Центральний державний історичний архів України у м. Києві, ф. 707, оп. 156, спр. 1, арк. 78 - 78 зв.

17. Отчёт попечителя Киевского учебного округа о состоянии учебных заведений округа за 1905 год. Центральний державний історичний архів України у м. Києві, ф. 442, оп. 659, спр. 14, арк. 230 - 485.

18. Письмо директора народных училищ Полтавской губернии господину попечителю Киевского учебного округа от 14 октября 1902 года № 3193 относительно запрета телесных наказаний учеников. Центральний державний історичний архів України у м. Києві, ф. 707, оп. 227, спр. 31, арк. 45 - 45 зв.

19. Письмо Министерства внутренних дел губернаторам, гродоначальникам и обер-полицеймейстерам от 17 августа 1904 года № 11109 о мерах по защите общественного порядка. Центральний державний історичний архів України у м. Києві, ф. 442, оп. 854, спр. 297, арк. 2 - 2 зв.

20. Письмо Министерства народного просвещения от 22 января 1904 года № 53 о допущении лиц польского происхождения к занятию некоторых должностей в учебных заведениях. - Центральний державний історичний архів України у м. Києві, ф. 707, оп. 68, спр. 2, арк. 1 - 1 зв.

21. Письмо Министерства народного просвещения господину попечителю учебного округа от 16 мая 1907 года № 10228 об открытии общеобразовательных курсов для учителей начальных училищ. Центральний державний історичний архів України у м. Києві, ф. 442, оп. 660, спр. 13, арк. 42.

22. Письмо Министерства народного просвещения директорам учительских институтов и семинарий от 31 декабря 1910 г. № 185 относительно воспитания учащихся. Центральний державний історичний архів України у м. Києві, ф. 707, оп. 229, спр. 1, арк. 53.

23. Письмо попечителя Киевского учебного округа от 11 января 1908 г. № 357 начальникам средних учебных заведений относительно утверждения лиц, не имеющих учительского звания. Центральний державний історичний архів України у м. Києві, ф. 707, оп. 74, спр. 2, арк. 1 - 1 зв.

24. Письмо попечителя Киевского учебного округа от 07 ноября 1909 г. № 50939 господину Киевскому, Подольскому и Волынскому генерал-губернатору относительно внедрения школьной сети начального образования в г. Киеве. Центральний державний історичний архів України у м. Києві, ф. 442, оп. 662, спр. 436, арк. 8.

25. Письмо попечителя Харьковского учебного округа господину Харьковскому отдельному цензору по внутренней цензуре от 08 марта 1901 г. № 2644 относительно требований педагогики. Центральний державний історичний архів України у м. Києві, ф. 1680, оп. 1, спр. 56, арк. 30 - 30 зв.

26. Письмо Харьковского губернатора исполняющему обязанности Харьковского отдельного цензора от 16 января 1902 г. № 350 о запрещении к печати статей, обсуждающих временные правила о студенческих организациях. Центральний державний історичний архів України у м. Києві, ф. 1680, оп. 1 , спр. 67 , арк. 8 .

27. Положение о высших начальных училищах, 1912 г. Центральний державний історичний архів України у м. Києві, ф. 707, оп. 229, спр. 1, арк. $281-286$.

28. Рождественский С. В. Исторический обзор деятельности Министерства народного просвещения. 1802 - 1902.С-Пб., 1902. 787 c.

29. Сірополко С. О. Історія освіти в Україні / Степан Сірополко. Київ: Наукова думка. 2001. 912 с.

30. Система школ и самостоятельная работа учащихся (Из цикла лекций, читанных народным учителем, директором народных училищ Т.Г. Лубенцем), 24 июня 1912 г. Центральний державний історичний архів України у м. Києві, ф. 707, оп. 229, спр. 150 а, арк. 27.

31. Україна-Свропа: хронологія розвитку. Т. 5: 1800 - 2010 рр. Київ: Кріон. 2011.926 с.

32. Устав Всероссийского Союза учителей и деятелей по народному образованию. Центральний державний історичний архів України у м. Києві, ф. 385, оп. 1, спр. 2357, арк. 217 - 223.

33. Устав Всероссийского Союза учителей и деятелей по народному образованию, 1905 г. Центральний державний історичний архів України у м. Києві, ф. 274, оп. 3, спр. 186, арк. $1-21$.

34. Устав Киевского общества распространения грамотности и просвещения, 1908 г. Центральний державний історичний архів України у м. Києві, ф. 442, оп. 662, спр. 5, арк. 55 - 79.

35. Устав Киевского общества классической филологии и педагогики // Сборник распоряжений по Министерству народного просвещения. Т. 15. 1901 - 1903 гг. С.-Пб.: Паровая Скоропечатня "Восток". 1904. С. $636-642$.

36. Устав педагогического отдела историко-филологического общества при Императорском Харьковском университете, 1905 г. Центральний державний історичний архів України у м. Києві, ф. 2017, оп. 1, спр. 412, арк. 1 - 5.

37. Циркуляр по управлению народными училищами, 1908 г. Центральний державний історичний архів України у м. Києві, ф. 442, оп. 661, спр. 2, арк. 107 - 122. 